Research Article

\title{
Water Quality Assessment of the Central Himalayan Lake, Nainital
}

\author{
Madhuben Sharma \\ University of Petroleum and Energy Studies, Bidholi, Dehradun, Uttarakhand 248007, India \\ Correspondence should be addressed to Madhuben Sharma; madhubensharma06@gmail.com
}

Received 14 July 2014; Revised 28 October 2014; Accepted 20 November 2014; Published 10 December 2014

Academic Editor: Paul M. Bradley

Copyright ( 2014 Madhuben Sharma. This is an open access article distributed under the Creative Commons Attribution License, which permits unrestricted use, distribution, and reproduction in any medium, provided the original work is properly cited.

\begin{abstract}
The Nainital Lake, situated in the central Himalayas of India, is an important water body and a major tourist spot. This study aims to identify factors or processes that determine the water quality of the lake. For this purpose, water samples from two different points were collected-highly polluted (Mallital) and least polluted (Tallital) - to represent the actual level of pollution in the lake in four different seasons (January, April, July, and October). The collected samples were analyzed for different physical and chemical parameters. In order to assess the state of the lake's water quality, the samples were compared with the standard water quality values. Turbidity, electrical conductivity, total alkalinity, and heavy metal (lead, iron, and copper) concentration were found to be above the desirable limit of the prescribed national and international standards in all four seasons at both Mallital and Tallital. Reasons affecting the water quality were found to be natural (thermal stratification and lead-bearing rocks) and anthropogenic (domestic sewage, runoff, and illegal construction activities in the vicinity of lake). Various lake restoration alternatives/interventions have been suggested that can lead to an improvement in the lake's water quality, such as afforestation, phytoremediation, and sediment basin.
\end{abstract}

\section{Introduction}

Nainital city is one of the major tourist attractions in the northern part of India. The lake provides water to 40,000 local inhabitants [1] and thousands of tourists visiting it every year [2] who use the water for different purposes like drinking and for recreational activities [3, 4]. Increasing local population, logarithmic increase in the tourist flux in Nainital, and the concomitant mushrooming of a large number of hotels in the catchment area have severely affected the water resources and biodiversity of this watershed $[5,6]$.

According to Singh et al. [7], open sewers disposing large quantities of sewage in the lake are definitely causing a detrimental effect on the lake water quality. Other anthropogenic activities such as illegal construction, litter, domestic discharge, and recreational use of lake water are major concerns for sedimentation and eutrophication of the lake water [1].

Thus, considering it as imperative, this comprehensive primary water quality monitoring study of the Nainital Lake has been undertaken. The main objective of this paper is to assess the state of water quality of the Nainital Lake by carrying out a comprehensive monitoring exercise to identify the contributing factors for the existing water quality. For this purpose, water samples were collected from a highly polluted and a least polluted site of the lake; 18 physicochemical parameters were analyzed to understand the limnology of the Nainital Lake. Various possible measures that can be put in place to maintain the desired water quality have also been discussed.

\section{Materials and Methods}

2.1. Study Area. The Nainital Lake is a natural kidney-shaped, tectonic, warm monomictic-type lake, situated at $29^{\circ} 24^{\prime} \mathrm{N}$ latitude and $79^{\circ} 28^{\prime} \mathrm{E}$ longitude [5]. It covers a surface area of 48 hectares. The maximum and mean depths of the lake are $27.3 \mathrm{~m}$ and $16.2 \mathrm{~m}$, respectively [2]. It is divided into two subbasins (Mallital and Tallital) by a $100 \mathrm{~m}$ wide transverse underwater ridge, $7 \mathrm{~m}$ below surface [5]. Mallital (north basin) is a highly polluted site due to intense boating activity and Naina Devi Mandir drain emptying into it. Tallital (south 
TABLE 1: Drinking water quality standards, units, analytical method, and recommending agencies (source: [8-10]).

\begin{tabular}{|c|c|c|c|}
\hline Water quality & Unit & Analytical method & $\begin{array}{l}\text { Indian standards (desirable) and } \\
\text { recommended agencies }\end{array}$ \\
\hline $\mathrm{pH}$ & $\mathrm{pH}$ unit & $\mathrm{pH}$ meter & 6.5-8.5 (BIS/ICMR) \\
\hline Turbidity & NTU & Turbidity meter & 5 (BIS) \\
\hline Dissolved oxygen & $\mathrm{mg} / \mathrm{L}$ & DO meter & 5 (ICMR) \\
\hline Electrical conductivity & $\mu \mathrm{s} / \mathrm{cm}$ & Conductivity meter & 300 (ICMR) \\
\hline Total dissolved solid & $\mathrm{mg} / \mathrm{L}$ & TDS meter & 500 (BIS) \\
\hline Total suspended solid & $\mathrm{mg} / \mathrm{L}$ & Gravimetric & $500(\mathrm{WHO})$ \\
\hline Temperature & $\begin{array}{l}\text { Degree } \\
\text { Celsius }\end{array}$ & Portable thermometer & - \\
\hline $\begin{array}{l}\text { Biochemical oxygen } \\
\text { demand }\end{array}$ & $\mathrm{mg} / \mathrm{L}$ & Winkler azide method & 5 (ICMR) \\
\hline Total hardness & $\mathrm{CaCO}_{3} \mathrm{mg} / \mathrm{L}$ & Titrimetric & 300 (BIS/ICMR) \\
\hline Total alkalinity & $\mathrm{CaCO}_{3} \mathrm{mg} / \mathrm{L}$ & Titrimetric & 120 (ICMR) \\
\hline Chloride & $\mathrm{mg} / \mathrm{L}$ & Argentometric & 250 (BIS/ICMR) \\
\hline Sodium & $\mathrm{mg} / \mathrm{L}$ & Flame photometer & $<20(\mathrm{WHO})$ \\
\hline Potassium & $\mathrm{mg} / \mathrm{L}$ & Flame photometer & $10(\mathrm{WHO})$ \\
\hline Phosphate & Microgram/L & UV spectrophotometer & - \\
\hline Lead & $\mathrm{mg} / \mathrm{L}$ & Atomic absorption & 0.05 (BIS) \\
\hline Copper & $\mathrm{mg} / \mathrm{L}$ & Atomic absorption & 0.05 (BIS) \\
\hline Iron & $\mathrm{mg} / \mathrm{L}$ & Atomic absorption & 0.3 (BIS) \\
\hline Zinc & $\mathrm{mg} / \mathrm{L}$ & Atomic absorption & 5 (BIS) \\
\hline
\end{tabular}

BIS: Bureau of Indian Standard, WHO: World Health Organization, and ICMR: Indian Council of Medical Research.

basin) on the other hand is relatively less polluted. Geology of both basins is one of the key interests for this study. The lake's basin is formed of folded and faulted rocks of Krol and Tal formation attributed to the Cambrian Age [11]. The lake receives water from springs (Pardadhara and Chunadhara), rainwater, and 22 inlet nullahs ( 9 are permanent, which act as a major conduit of polluted sludge and silt draining off into the lake) [1]. The lake supports around 40,000 local inhabitants present in its catchment area; hence, anthropogenic activities like surface runoff, domestic sewage, construction activities, and agricultural activities have significantly changed the water quality of the Nainital Lake.

2.2. Sample Collection and Analysis. Water samples were collected from two sites of Nainital-Mallital (L1) and Tallital (L2) (Figure 1). Fourteen grab samples were collected for each month (January, April, July, and October) from both the sites. In order to collect representative samples, a sampling station network was designed in such a way so as to cover wide range of factors such as drains and springs that influence the water quality of the lake. Water samples were collected in 2,000 mL polyethylene sterilized bottles (cleaned with metal-free soap, washed with distilled water, soaked in $10 \%$ nitric acid for 24 hours, and finally rinsed with ultrapure water). Water samples were stored in an insulated, ice-cooled container and delivered to the laboratory on the same day. All the samples were kept at $4^{\circ} \mathrm{C}$ to avoid physicochemical changes and interference. The sampling, preservation, transportation,

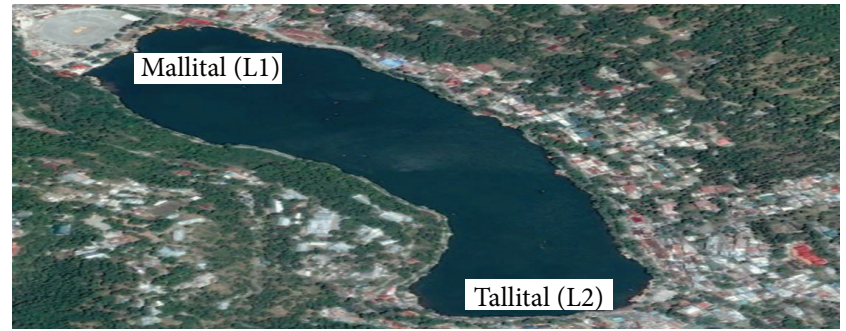

FIGURE 1: Map showing the study area and surface water quality sampling stations of Nainital Lake (source: Google map).

and analysis of water samples were carried out according to the methods described in APHA-AWWA-WEF (1998) [12]. The polyethylene bottles used for storing samples were sealed with tape to make the sample free from air contact. Surface runoff, domestic sewage, and weathering of rocks were found to be responsible for influencing the physical and chemical parameters of the Nainital Lake water. A total of 18 physicochemical parameters were analyzed in laboratory using standard protocol APHA-AWWA-WEF (1998) including total dissolved solids (TDS), total suspended solid (TSS), turbidity, electrical conductivity (EC), phosphate, total hardness, $\mathrm{pH}$, alkalinity, temperature, $\mathrm{BOD}, \mathrm{DO}, \mathrm{Cl}, \mathrm{Na}+, \mathrm{Pb}$, $\mathrm{K}, \mathrm{Cu}, \mathrm{Fe}$, and $\mathrm{Zn}$. Water quality parameters, unit, methods of analysis, Indian standards, and recommended agencies are all summarized in Table 1. 
TABle 2: Descriptive statistics of water quality parameters for Nainital Lake for all 4 seasons (January, April, July, and October).

\begin{tabular}{|c|c|c|c|c|c|c|}
\hline \multirow{3}{*}{ Parameter } & \multicolumn{3}{|c|}{ Nainital Lake (Mallital) } & \multicolumn{3}{|c|}{ Nainital Lake (Tallital) } \\
\hline & \multicolumn{2}{|c|}{ For all 4 seasons } & \multirow{2}{*}{ Mean \pm Std. deviation } & \multicolumn{2}{|c|}{ For all 4 seasons } & \multirow{2}{*}{ Mean \pm Std. deviation } \\
\hline & Maximum & Minimum & & Maximum & Minimum & \\
\hline $\mathrm{PO}_{4}^{-3}$ & 0.18 & 0.09 & $0.143 \pm 0.046$ & 0.16 & 0.09 & $0.123 \pm 0.036$ \\
\hline Temp. & 22.00 & 17.00 & $19.50 \pm 2.08$ & 22.00 & 18.00 & $20.50 \pm 1.73$ \\
\hline $\mathrm{DO}$ & 8.60 & 7.90 & $8.20 \pm 0.29$ & 7.20 & 4.00 & $5.77 \pm 1.39$ \\
\hline $\mathrm{pH}$ & 8.20 & 7.20 & $7.55 \pm 0.47$ & 8.20 & 7.40 & $7.75 \pm 0.34$ \\
\hline BOD & 3.50 & 2.80 & $3.25 \pm 0.33$ & 4.80 & 3.80 & $4.25 \pm 0.41$ \\
\hline Turbidity & 16.00 & 6.00 & $10.25 \pm 4.64$ & 18.00 & 6.00 & $10.50 \pm 5.25$ \\
\hline $\mathrm{TH}$ & 290.00 & 192.00 & $250.00 \pm 41.53$ & 392.00 & 112.00 & $241.50 \pm 125.9$ \\
\hline $\mathrm{TA}$ & 278.00 & 230.00 & $253.50 \pm 21.56$ & 154.00 & 120.00 & $142.00 \pm 15.05$ \\
\hline TDS & 422.00 & 375.00 & $400.00 \pm 23.05$ & 582.00 & 359.00 & $443.25 \pm 98.29$ \\
\hline TSS & 390.00 & 286.00 & $338.00 \pm 44.92$ & 412.00 & 258.00 & $341.25 \pm 68.62$ \\
\hline $\mathrm{Cl}$ & 18.00 & 11.00 & $14.50 \pm 2.88$ & 19.00 & 14.00 & $16.750 \pm 2.62$ \\
\hline EC & 580.00 & 500.00 & $536.00 \pm 33.62$ & 550.00 & 500.00 & $525.00 \pm 28.86$ \\
\hline $\mathrm{Na}$ & 3.20 & 2.42 & $2.79 \pm 0.40$ & 3.30 & 2.89 & $3.14 \pm 0.18$ \\
\hline $\mathrm{K}$ & 14.57 & 11.80 & $12.82 \pm 1.20$ & 11.24 & 10.27 & $10.57 \pm 0.45$ \\
\hline $\mathrm{Pb}$ & .34 & .24 & $0.28 \pm 0.04$ & .27 & .21 & $0.23 \pm 0.02$ \\
\hline $\mathrm{Cu}$ & .24 & .14 & $0.19 \pm 0.04$ & .22 & .18 & $0.20 \pm 0.01$ \\
\hline $\mathrm{Fe}$ & .73 & .62 & $0.68 \pm 0.04$ & .79 & .64 & $0.70 \pm 0.06$ \\
\hline $\mathrm{Zn}$ & .08 & .03 & $0.06 \pm 0.02$ & .07 & .02 & $0.04 \pm 0.02$ \\
\hline
\end{tabular}

\section{Result and Discussion}

The different physicochemical parameters of the lake water are discussed below and compared with WHO/BIS/ICMR standards. The descriptive statistics for both sites (Mallital and Tallital) are presented in Table 2.

The lake water appears to be alkaline in nature in all four seasons with the $\mathrm{pH}$ value ranging between 6.5 and 8.2. Maximum $\mathrm{pH}$ was recorded at Mallital in July and October and at Tallital in April. Purohit and Singh [4] too reported high $\mathrm{pH}$ in the lake for the said period (JulyNovember). Increase in photosynthetic activity of submerged and suspended algal population in aquatic ecosystem may be the reason for this increase in $\mathrm{pH}$ value.

Total alkalinity recorded in the Nainital Lake water ranges between $230 \mathrm{mg} / \mathrm{L}$ to $278 \mathrm{mg} / \mathrm{L}$ at Mallital and between $120 \mathrm{mg} / \mathrm{L}$ to $154 \mathrm{mg} / \mathrm{L}$ at Tallital. The maximum concentration of alkalinity was recorded during July season at both the sites. During monsoon, surface runoff brings organic matter and, with decomposition of this organic matter, carbon dioxide is released resulting in the addition of carbonate and bicarbonate, which also increases the alkalinity value.

Dissolved oxygen (DO) is the indication of general health of a water body. DO recorded in the water of the Nainital Lake ranges between $7.9 \mathrm{mg} / \mathrm{L}$ to $8.6 \mathrm{mg} / \mathrm{L}$ at Mallital and between $4 \mathrm{mg} / \mathrm{L}$ to $7.2 \mathrm{mg} / \mathrm{L}$ at Tallital. The maximum amount of DO in the water of the lake was recorded during April at Mallital and in October season at Tallital. This can be explained by the fact that during active photosynthesis more oxygen gets dissolved in the lake $[13,14]$.

Biochemical oxygen demand (BOD) is a key parameter and it indicates the organic load in aquatic ecosystem.
BOD value in the Nainital Lake ranges between $2.8 \mathrm{mg} / \mathrm{L}$ to $3.5 \mathrm{mg} / \mathrm{L}$ at Mallital and between $3.8 \mathrm{mg} / \mathrm{L}$ to $4.8 \mathrm{mg} / \mathrm{L}$ at Tallital, which was within the desirable limit of drinking water quality standards for all four seasons.

The minimum concentration of phosphate (93.12 micrograms/l to 88.65 micrograms/l) was recorded during January at both the sites (Mallital and Tallital) of the lake. Maximum concentration of phosphate (162.76 micrograms/l) was recorded during April at Tallital and in October (184.68 micrograms/l) at Mallital.

Electrical conductivity (EC) varies between $500 \mathrm{mg} / \mathrm{L}$ to $580 \mathrm{mg} / \mathrm{L}$ at Mallital and between $500 \mathrm{mg} / \mathrm{L}$ to $550 \mathrm{mg} / \mathrm{L}$ at Tallital. Maximum EC $(580 \mathrm{mg} / \mathrm{L})$ was reported at Mallital in the month of April and (550 mg/L) in April and October at Tallital. EC in the lake is controlled by surface runoff in summer and subsurface runoff during monsoon and early spring. Concentration of total suspended solids (TSS) varies from $286 \mathrm{mg} / \mathrm{L}$ to $390 \mathrm{mg} / \mathrm{L}$ at Mallital and from $258 \mathrm{mg} / \mathrm{L}$ to $412 \mathrm{mg} / \mathrm{L}$ at Tallital for different seasons. Maximum concentration was recorded at Mallital in April $(390 \mathrm{mg} / \mathrm{L})$ and in July (412 mg/L) at Tallital. Total dissolved solid (TDS) in Nainital Lake ranges between $375 \mathrm{mg} / \mathrm{L}$ and $422 \mathrm{mg} / \mathrm{L}$ for Mallital and between $359 \mathrm{mg} / \mathrm{L}$ and $582 \mathrm{mg} / \mathrm{L}$ for Tallital. The maximum amount of TDS was recorded during July at both sites. This increased concentration of TDS in the Nainital Lake was attributed to surface runoff. Results for EC and TDS show conformance with the previous study [15].

Presence of clay, silt, organic matter, phytoplankton, and other microscopic organisms causes turbidity in lake water. Presence of high turbidity indicates the presence of large amount of suspended solids. Turbidity in Nainital Lake was recorded in ranges between $6 \mathrm{NTU}$ to $16 \mathrm{NTU}$ for Mallital 
and between $6 \mathrm{NTU}$ to $18 \mathrm{NTU}$ for Tallital. The maximum turbidity (16 NTU and 18 NTU) in water was recorded during the month of July at both the sites. Again this high turbidity during July can be attributed to particulate addition through surface runoff from the surrounding hills. Also, an increase in population and cultural activities leading to massive deforestation and waste generation in the catchment of Nainital Lake in turn leading to an increased concentration of suspended solids can also affect the turbidity in the Nainital Lake. The mean turbidity values obtained for Nainital Lake were in conformance with the values as reported in literature [4].

Total hardness recorded in the water of Nainital Lake for present investigation ranges between $192 \mathrm{mg} / \mathrm{L}$ to $290 \mathrm{mg} / \mathrm{L}$ and between $112 \mathrm{mg} / \mathrm{L}$ to $392 \mathrm{mg} / \mathrm{L}$ for both sites, respectively. The maximum concentration of total hardness in the water of Nainital Lake was recorded during April at Tallital (392 mg/L). High temperature, evaporation of water, weathering of rocks, and addition of calcium and magnesium salts by means of plants and living organism were found to be contributing factors for the hardness of the lake water.

Concentration of potassium $(\mathrm{K})$ varied from $11.8 \mathrm{mg} / \mathrm{L}$ to $14.57 \mathrm{mg} / \mathrm{L}$ for Mallital and from $10.27 \mathrm{mg} / \mathrm{L}$ to $11.24 \mathrm{mg} / \mathrm{L}$ for Tallital. Maximum potassium concentration was observed at both the sampling sites during July. It was found that, during rains, wastewater drains (Nallahs) in the catchment area were responsible for the increased potassium concentration as the runoff consisted of decomposed organic waste and plant material which increases the concentration of potassium in the lake water. Similar finding has been projected by Trivedy et al. [16]. Seasonally, concentration of sodium (Na) in Nainital Lake varied from $2.42 \mathrm{mg} / \mathrm{L}$ to $3.2 \mathrm{mg} / \mathrm{L}$ and from $2.8 \mathrm{mg} / \mathrm{L}$ to $3.3 \mathrm{mg} / \mathrm{L}$ for both sites, respectively. Chloride recorded in the water ranged between $7 \mathrm{mg} / \mathrm{L}$ to $11 \mathrm{mg} / \mathrm{L}$ (Mallital) and between $14 \mathrm{mg} / \mathrm{L}$ to $19 \mathrm{mg} / \mathrm{L}$ (Tallital). The concentration of sodium and chloride in Nainital Lake did not exceed the WHO and BIS recommended values.

3.1. Distribution of Heavy Metals in Lake Water. It was found that seasonally the concentration of lead $(\mathrm{Pb})$ in the Nainital Lake ranged between $0.21 \mathrm{mg} / \mathrm{L}$ to $0.34 \mathrm{mg} / \mathrm{L}$ for both the sites (Mallital and Tallital) and maximum lead was reported in October at both sites. The reasons for increased lead concentration were found to be anthropogenic activities (boat repairing, painting), presence of automobile workshop on the banks of the lake, and lead-bearing minerals present in the catchment rock formation [15]. During winter, as the top layers become cooler in comparison to the deeper layers, the sinking process starts which shows greater mixing during winter in comparison to summer (April) when it is thermally stratified. In this study, the concentration of lead obtained was higher than the permissible limit of BIS, hence, making the lake water unsuitable for drinking and domestic use. The unsuitability of such water is corroborated by Schwartz et al. [17], who reported that high concentration of lead leads to growth retardation in children.

Copper $(\mathrm{Cu})$ concentration varied between $0.14 \mathrm{mg} / \mathrm{L}$ and $0.24 \mathrm{mg} / \mathrm{L}$ throughout the study period. It was reported to be
TABLE 3: Suitable interventions for the remediation of the Nainital Lake water.

\begin{tabular}{|c|c|c|}
\hline $\begin{array}{l}\text { Sr. } \\
\text { number }\end{array}$ & Techniques & Discussion \\
\hline 1 & Afforestation & $\begin{array}{l}\text { Control soil erosion from nearby } \\
\text { hills, which further helps in } \\
\text { controlling turbidity of the lake } \\
\text { water. }\end{array}$ \\
\hline 2 & Phytoremediation & $\begin{array}{l}\text { Growing common aquatic plants } \\
\text { like bulrush, water hyacinth, } \\
\text { duckweed, hydrilla, and lotus in } \\
\text { the catchment area and inside the } \\
\text { Nainital Lake will help in the } \\
\text { removal of heavy metals from the } \\
\text { surface runoff and lake water. }\end{array}$ \\
\hline 3 & Sediment basin & $\begin{array}{l}\text { Basin is rectangular in shape, } \\
\text { formed by excavation or by } \\
\text { constructing embankment. It } \\
\text { reduces water flow by trapping } \\
\text { maximum amount of sediments } \\
\text { having efficiency of settling } \\
\text { particle of size up to } 0.005 \mathrm{~mm} \text {, } \\
\text { thereby making downstream } \\
\text { water free from debris. }\end{array}$ \\
\hline
\end{tabular}

highest in July at both sites; Mallital recorded $0.24 \mathrm{mg} / \mathrm{L}$ and Tallital recorded $0.22 \mathrm{mg} / \mathrm{L}$, respectively. Leaching of metals from the catchment soil and from market waste/effluent into rainwater [2] and then transporting into the lake water increased the concentration of copper in the Nainital Lake water.

Concentration of iron $(\mathrm{Fe})$ ranged between $0.62 \mathrm{mg} / \mathrm{L}$ and $0.79 \mathrm{mg} / \mathrm{L}$. It was found to be highest in April at Mallital $(0.73 \mathrm{mg} / \mathrm{L})$ and in January at Tallital $(0.79 \mathrm{mg} / \mathrm{L})$. Increased concentration of iron in itself is not a pollutant but it provides a favorable condition for many pathogenic organisms to grow as they require iron to thrive.

The concentration of zinc $(\mathrm{Zn})$ varied between $0.02 \mathrm{mg} / \mathrm{L}$ and $0.08 \mathrm{mg} / \mathrm{L}$ for both sites and was reported to be within the desirable level as per BIS standards.

Based on this study, it was found that at both the sites of Nainital Lake (Mallital and Tallital), surface runoff and heavy metals (lead, copper, and iron) were the main contributors of water pollution. In order to control the surface runoff and for the rejuvenation of the Nainital Lake water, suitable interventions have been discussed in Table 3 .

\section{Conclusion}

The study reveals that turbidity, total alkalinity, electrical conductivity, and heavy metal (lead, copper, and iron) were found to be above the desirable limit of BIS/ICMR/WHO standard in all four seasons at Mallital and Tallital. The lake water quality deterioration is caused by domestic sewage, surface runoff from nearby hills, deforestation, and natural activities (thermal stratification, lead-bearing rocks). Suitable lake restoration measures/interventions as mentioned above should be adopted to reduce anthropogenic discharges into 
the lake basin; otherwise, high levels of pollutants will bring about a negative effect on the lives of the surrounding population and their socioeconomic conditions.

\section{Conflict of Interests}

The author declares that there is no conflict of interests regarding the publication of this paper.

\section{References}

[1] P. Purushothaman, S. Mishra, A. Das, and G. J. Chakrapani, "Sediment and hydro biogeochemistry of Lake Nainital, Kumaun Himalaya, India," Environmental Earth Sciences, vol. 65, no. 3, pp. 775-788, 2012.

[2] R. Gupta, P. Bhagat, M. Joshi, S. Inaotombi, and P. K. Gupta, "Heavy metal pollution status of Lake Nainital, Uttarakhand," Indian Journal of Scientific Research, vol. 1, no. 1, pp. 15-19, 2010.

[3] D. S. Misra, J. Pande, and S. M. Das, "Studies on bacteriological quality of nainital lake water in different seasons," Water, Air, and Soil Pollution, vol. 19, no. 2, pp. 149-154, 1983.

[4] R. Purohit and S. P. Singh, "Seasonal variation in physicochemical limnology of shallow zones of Nainital Lake, Western Himalaya (India)," Proceedings of the Indian National Science Academy, Section B: Biological Sciences, vol. 47, no. 2, pp. 194203, 1981.

[5] C. K. Jain, D. S. Malik, and R. Yadav, "Metal fractionation study on bed sediments of Lake Nainital, Uttaranchal, India," Environmental Monitoring and Assessment, vol. 130, no. 1-3, pp. 129-139, 2007.

[6] S. Shah, A. Tewari, and B. Tewari, "Impact of human disturbance on forest vegetation and water resources of nainital catchment," Nature and Science, vol. 7, no. 10, pp. 74-78, 2009.

[7] S. P. Singh, G. Brij, K. K. Vinish, C. Malavika, U. Manisha, and B. Mohan, "Integrated management of water resources of lake nainital and its watershed: an environmental economics approach," in The World Bank Aided "India Environmental Management and Capacity Building" Technical Assistance Project, EERC, Indira Gandhi Institute for Developmental Research, Mumbai, India, 2001-2002.

[8] BIS, Standards for Water for Drinking and Other Purposes, BIS, New Delhi, India, 2003.

[9] ICMR, "Manual of standards of quality for drinking water supplies," ICMR, New Delhi, India, 1975.

[10] WHO, Guidelines for Drinking Water Quality, vol. 1 of Recommendations, WHO, Geneva, Switzerland, 3rd edition, 2004.

[11] "Water balance of lake Nainital, Kumaun Himalayas," U.P, National Institute of Hydrology Roorkee, 1-62, CS(AR)-6/9899,(1989-1999).

[12] American Public Health Association, Standard Methods for Examination of Water and Waste Water, American Public Health Association, New York, NY, USA, 1998.

[13] R. N. Singhal, Swaranjeet, and R. W. Davies, "The physicochemical environment and the plankton of managed ponds in Haryana, India," Proceedings of the Indian Academy of Science, Section B, vol. 95, no. 3, pp. 353-363, 1986.

[14] A. Sreenivasan, V. K. Pillai, and T. Franklin, "Limnological study of a shallow water body (Kolovoi Lak) in Tamil Nadu, India," Journal of Indian Hydrobiology, vol. 2, no. 2, pp. 61-69, 1997.

[15] "Water quality studies of lake Nainital and surroundings," 1-127, CS (AR)-1, National Institute of Hydrology Roorkee, 1999/2000.
[16] R. K. Trivedy, P. K. Goel, and C. L. Trisal, Practical Methods in Ecology and Environmental Science, Environmental Publications, Karad, India, 1987.

[17] J. Schwartz, C. Angle, and H. Pitcher, "Relationship between childhood blood lead levels and stature," Pediatrics, vol. 77, no. 3, pp. 281-288, 1986. 

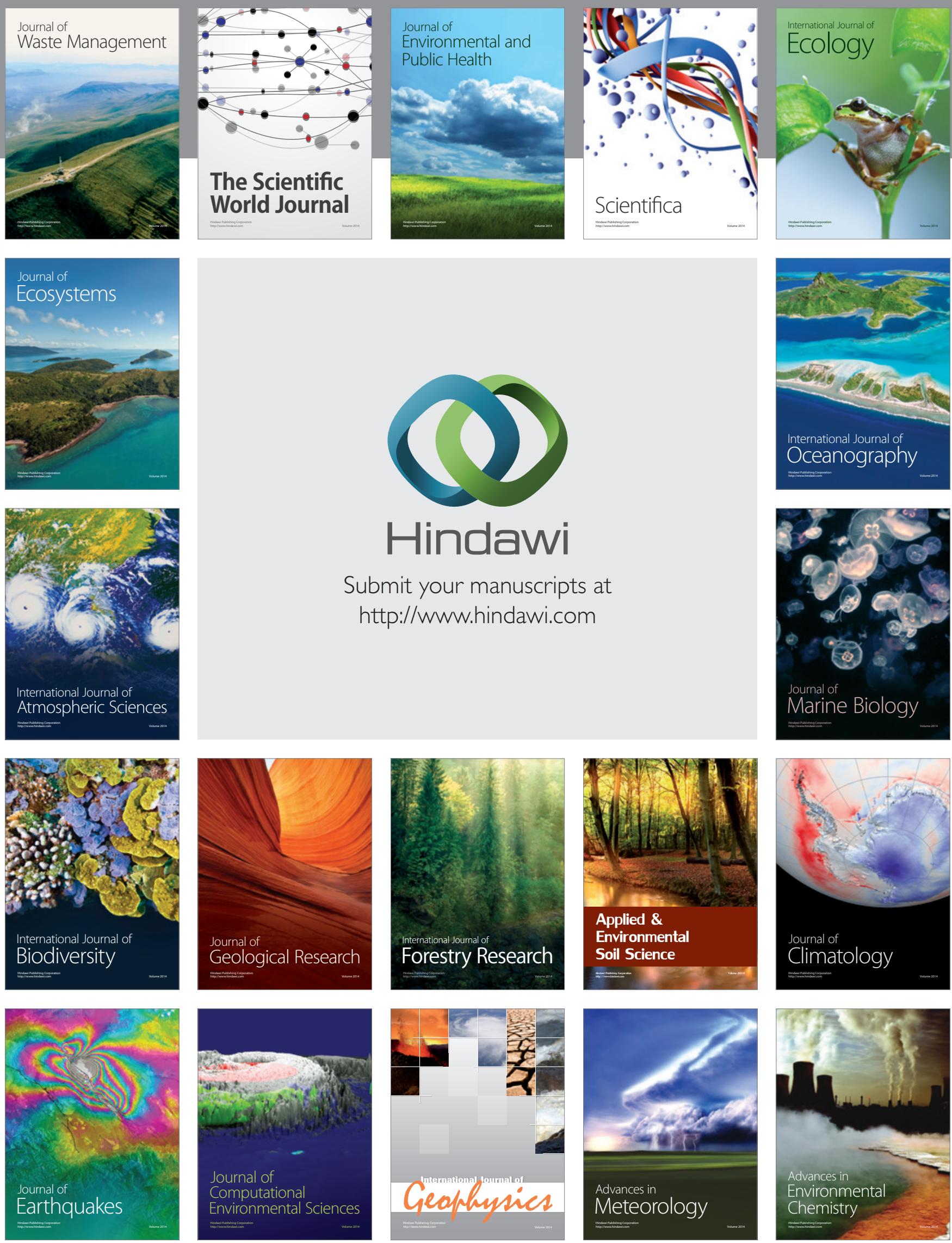